\title{
Runway design and structural design of an airfield pavement.
}

\author{
Sundeep Chowdary Daggubati ${ }^{1}$, Nazneen ${ }^{2}$, Subham Sharma ${ }^{3}$, Sulabh raj \\ gurung 4
}

1,2,3 \& 4-Bachelor of Engineering (Civil), Final year, Department of Civil Engineering, Hindustan

University, India,

\begin{abstract}
The growth of air transportation is one of the most remarkable technological developments of last century. The phenomenal increase in air-travel, has created severe congestion at the airports in the large cities, needing additional facilities for rapidly growing short-haul domestic markets. The studies by ICAO in 2010 showed that the existing terminals and runways would be inadequate to handle air traffic and the Chennai International airport will saturate by 2015 and so The Greenfield Airport at Sriperumbudur was proposed.

"Runway design and the Structural design of Airfield pavement" is a region specific project work that aims to geometrically design the runway and orient it considering all the factors that affect it including the environmental norms and regulations. Meteorological survey, Geological survey, Topographic survey, Drainage survey and Reconnaissance surveys are done in and around the proposed airport site. All the factors affecting site selection are considered and cross checked with the proposed site conditions and location. Meteorological data of the proposed site is obtained from the reliable web sites that depend on the Polar Orbiting Satellite Systems. Enviroware'sWindRose PRO3 software is used to analyse and plot the raw wind data of one year duration graphically as a wind-rose diagram. FAA guidelines and ICAO design criteria are strictly followed in the design and orientation of the runway. FAA designed software tools like FAARFIELD 2.5, F806FAA.xls and LEDFAA 13 were used to do the design of structural airfield pavement.
\end{abstract}

Keywords: Airfield pavement, Airport, Design, FAA, ICAO, Orientation, Runway, Windrose.

\section{Introduction}

The growth of economy of any country depends upon the development of transportation. In country like India, having second largest system of railways in the world and fully developed highway transportation, there is growing demand for air transportation. Demands for larger capacity and more facilities at the airports are increasing at a faster rate. The increased number of airlines and their increasing fleet size and flight frequencies has created competitive domestic services with fare reductions, in spite of zooming oil prices. Indian airport besides runway capacities are also lacking very much in accommodating new airline offices and their demands for handling passengers. Present growth rate places Indian airports among the fastest growing in the world, next to China.

The parallel runway was proposed in 2006 after studies showed that the existing terminals and runways would be inadequate to handle air traffic and the existing Chennai airport will saturate by 2015.The Rs.2000crore expansion project, considered important for the Tamil Nadu State's infrastructure development, got delayed owing to various reasons. The ICAO study, published in 2010, recommended that a parallel runway need not be constructed if a new airport was going to be built at Sriperumbudur. A Greenfield airport is a necessity for Chennai as there is acute congestion and as an alternative solution. The AAI considered the proposed second airport at Sriperumbudur, for which the International Civil Aviation Organisation has completed a feasibility study and submitted a report. Apart from these issues, the development of airports in Coimbatore and Madurai and according international status for the Coimbatore airport were also under consideration. A design paper like this on Airport Engineering is essential in accomplishing the technical resources required for investment in airways, airport improvements and development of new airports.

\subsection{General}

\section{Development Of New Airports}

Before deciding to develop a new airport, full consideration should be given to the possibility of improving the existing airport capacity so as to make it suitable for the increased future air traffic. Efforts should be made to accommodate new types of aircrafts likely to ply in the near future.

\subsection{Improving existing airport}

The following are the steps for a scientific approach for improving the existing airport: 
Runway design and structural design of an airfield pavement.

\subsubsection{Traffic forecast}

The following data is collected for the traffic forecast:

Area to be served, Origin and destination of residents and non-residents of the area, Population growth in that area, Economic character of the area

\subsubsection{Determination of the capacity of existing airport 2.2.3 Improvement of airport capacity}

The improvement can be done in the following ways: Runway extensions, new or parallel runways and high speed exit taxiways, Rearranging or increasing the size of terminal building and loading apron, improving the traffic control devices. In spite of all the possible ways as listed above, if it is worked out that the present airport cannot handle the air traffic, the designer thus arrives at the obvious answer, i.e. to propose a new airport.

\subsection{Data required before site selection:}

Having decide to develop a new airport, the first thought that comes to the design engineer is regarding the selection of a suitable site. Before this is done, the following information concerning the future airport are gathered:1) Peak hourly volume of air traffic to be handled; 2) The present and future types of aircrafts which may use the airport. Besides this their characteristics like the size, turning radius, encircling radius, weight and wheel configuration etc. should also be studied. 3) Facilities to be provided for the passengers, baggage and cargo, for landing and take-off and servicing of aircrafts should be considered. This decides the type of airport to be developed. Based on the classification of airport, the geometric standards of approaches, runways and taxiways are determined. Thus the planner gets an idea of the approximate land size required for developing a new airport. The limits of the maximum altitudes of the topographical and man-made features in the approach zones and turning zones can also be decided.

\subsection{About sriperumbudur}

\section{The Greenfield Airport, Sriperumbudur.}

Sriperumbudur is a Class IV town located about $45 \mathrm{~km}$, south west of Chennai on the ChennaiBengaluru NH-4. It is a Taluk head quarter town and well connected by transport arteries connecting various towns in the region. The nearest airport is located at Chennai; nearest railway stations are Avadi and Thiruvallur. The nearest port is Chennai port and airport is at Meenambakkam. The Government of Tamil Nadu has setup SIPCOT industrial layouts and SEZs on the National Highway-4 corridor which led to the rapid industrialisation of the region.

\subsection{Heritage and tourism}

Sriperumbudur town earlier known as 'Boothaburi' was an agrarian community dating back to the first millennia. The town has a rich cultural and religious heritage and is well known as the birthplace of the Vaishnavite Saint Shri Ramanujar. The town is endowed with many structures of heritage significance apart from the AdhikesavaPerumal temple, namely, the Boothabureeswarar Temple, ManavalaMaamuni temple, ThaanThondri Amman Temple and many Mandapams of heritage value

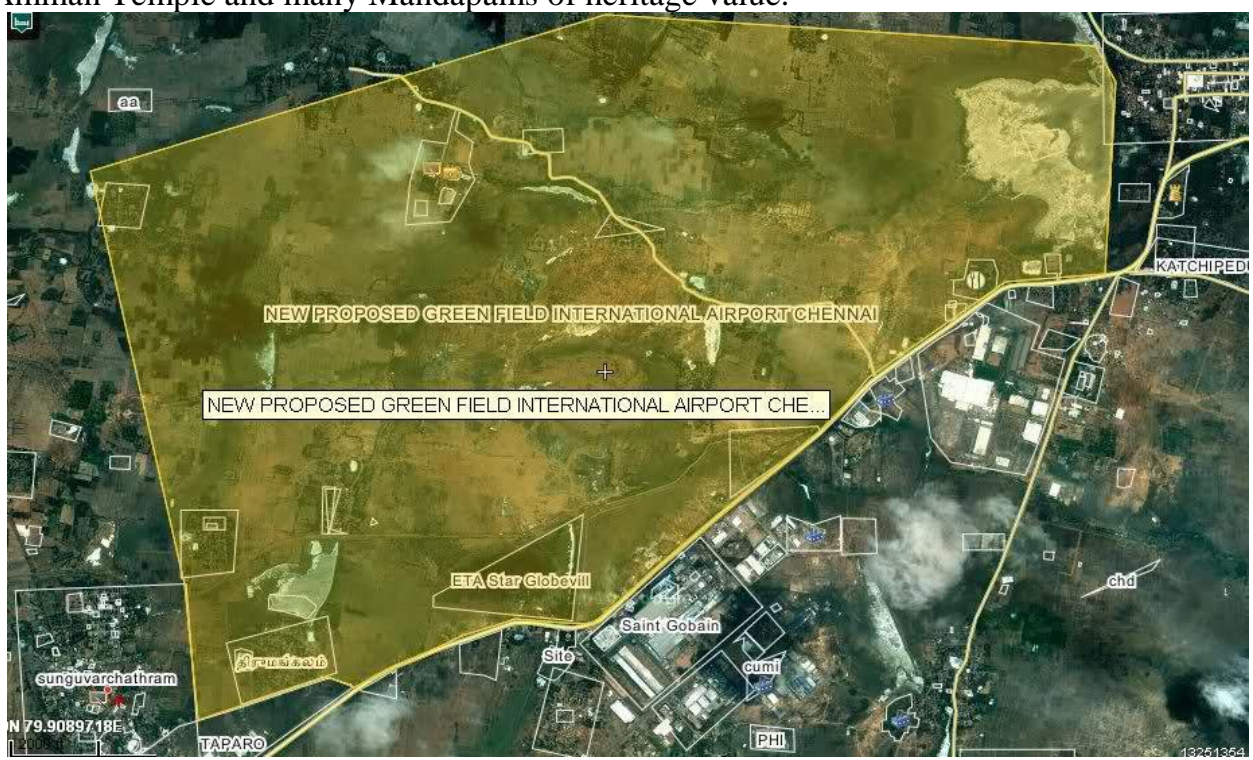

Figure 1: Proposed site near ETA star Globvill, Saint Gobain and Sunguvarichthram. 
Table 1Sriperumbudur's SWOT

\begin{tabular}{|c|c|}
\hline Strength & Weakness \\
\hline One of the three major development corridors of Chennai. & $\begin{array}{l}\text { High land value - proliferation of real estate leading to } \\
\text { speculation and scattered development in the regional } \\
\text { level. }\end{array}$ \\
\hline $\begin{array}{l}\text { Proximity to Chennai Sea Port and Airport \& Industrial Corridor of Excellence, } \\
\text { housing more than } 500 \text { small \& large scale industries, Employing more than } 2 \\
\text { lakh people. }\end{array}$ & $\begin{array}{l}\text { Unplanned growth - development of industries and } \\
\text { residences will further complicate the infrastructure } \\
\text { provision }\end{array}$ \\
\hline $\begin{array}{l}\text { Technology hub global industries like Hyundai, Saint Gobain, Nokia, Ford, } \\
\text { Hindustan Motors, Mitsubishi, BMW, Dell and Presence of Global Automotive } \\
\text { Research. }\end{array}$ & $\begin{array}{l}\text { Travel time from residence at Chennai to work place on } \\
\text { the Corridor. }\end{array}$ \\
\hline Skilled manpower and active Government support for cluster development. & $\begin{array}{l}\text { Inadequate quality social infrastructure in terms of } \\
\text { education, medical, recreational facilities to attract } \\
\text { professional industrial employees. }\end{array}$ \\
\hline Opportunities & Threats \\
\hline $\begin{array}{l}\text { Proposed Chennai-Bengaluru Industrial corridor, exclusive freight corridor, } \\
\text { Exclusive lanes to sea port and airports, and extension of Metro rail is expected } \\
\text { to give a further fillip to economic growth in southern India. }\end{array}$ & $\begin{array}{l}\text { Rapid conversion of Agricultural land into industrial } \\
\text { and residential uses. }\end{array}$ \\
\hline $\begin{array}{l}\text { With location advantage, the region has the capacity to attract many potential } \\
\text { developers }\end{array}$ & Exploitation of natural resources due to urbanisation. \\
\hline Leading destination for Foreign Direct Investments. & $\begin{array}{l}\text { Absence of Regional Plan to guide Socio-economic } \\
\text { development of the region }\end{array}$ \\
\hline
\end{tabular}

Table 2: Sriperumbudur's Raod Connectivity

\begin{tabular}{|c|l|l|}
\hline SI.No. & Road Connectivity & Classification of Road \\
\hline 1 & Sriperumbudur - Chennai on the North east & National Highway -4 \\
\hline 2 & Sriperumbudur-Ranipet on the South west & National Highway -4 \\
\hline 3 & Sriperumbudur - Thiruvallur on the North & State Highway-57 \\
\hline 4 & Sriperumbudur-Singamperumal Kovil on the south & State Highway- 57 \\
\hline 5 & Sriperumbudur- Kundrathur on the east & State Highway -113 \\
\hline 6 & Sriperumbudur- Tambaram on the South west & State Highway -110 \\
\hline
\end{tabular}

The above tabulation shows that Sriperumbudur is well connected with both the National Highways and State Highways.

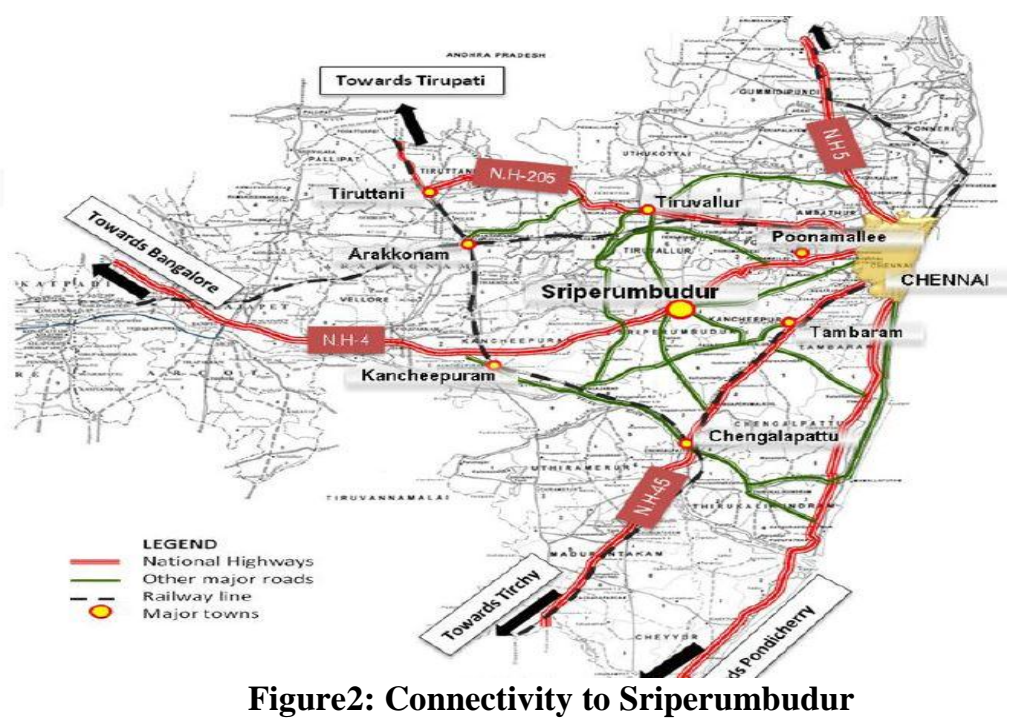

\subsection{Meteorological survey}

\section{Surveys for Site Selection}

To determine the direction, duration and intensity of wind, rainfall, fog, temperature and barometric pressure etc. The following wind data is collected from the reliable web sources that depend upon the Polar Orbiting Satellite Systems for the weather forecast or report of a region based on the user given input data like the latitude and longitude of the required location or site.

Location: Sunguvarichathiram near Sriperumbudur, north-west of Chennai.

Latitude and Longitude: $12.9700-\mathrm{N}, 79.9500-\mathrm{E}$

$$
\text { 12- 58' 8" N, 79- 56' 56" E. }
$$

Indian Standard Time: UTC+05:30 
Elevation: $37 \mathrm{~m}$ (121 feet)

The raw data collected includes the following:

$>$ Wind data: Speed and Direction.

$>$ Sky: Cloudy/Clear/Overcast

$>$ Rain

$>$ Temperature

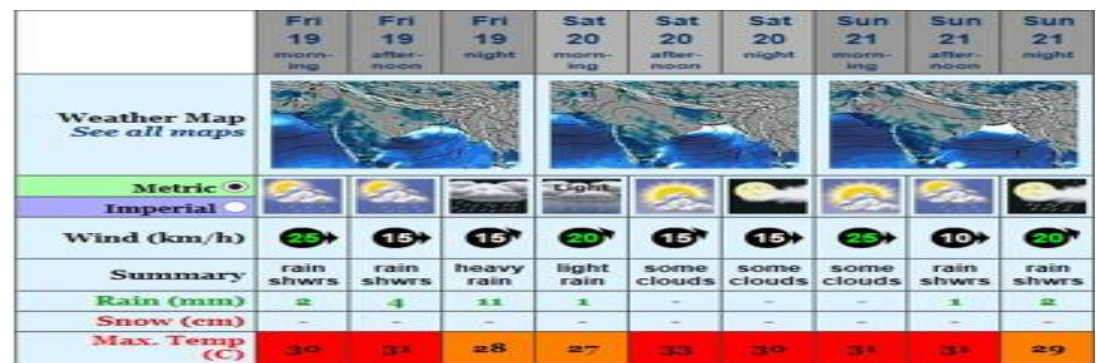

Figure3: Meteorological report of the Sriperumbudur region on $19^{\text {th }}, 20$ th and $21^{\text {st }}$ August 2013

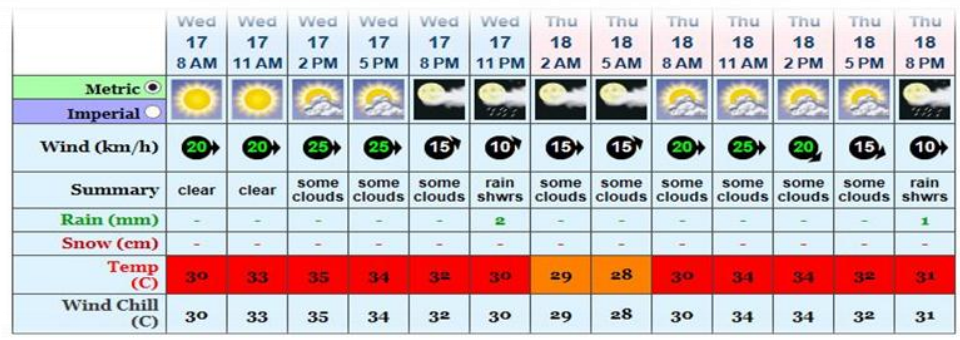

Figure 4: A 3 hr detailed report on $17^{\text {th }}$ and $18^{\text {th }}$ August 2013

\subsection{Topographical survey}

To prepare contour map showing other natural features such as trees, streams, buildings, roads etc.

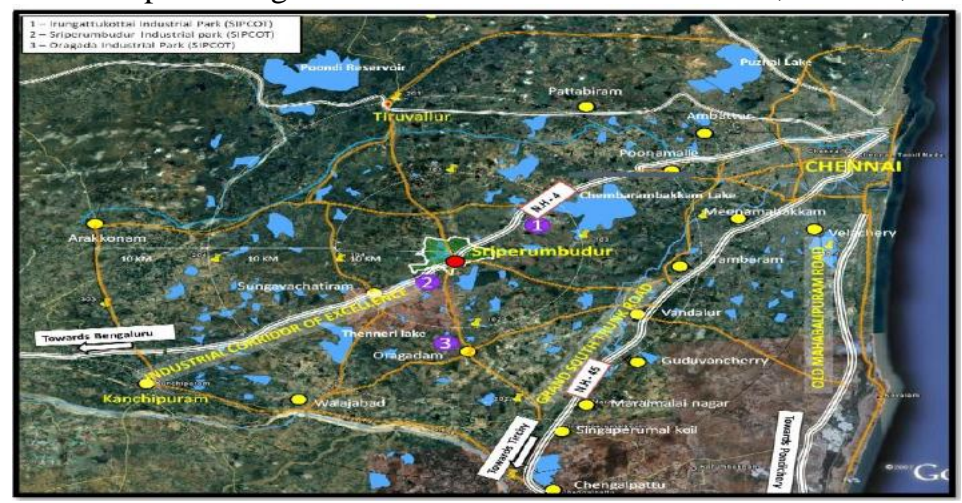

Figure 5: Map showing water bodies, roads and other villages and towns connecting Sriperumbudur 


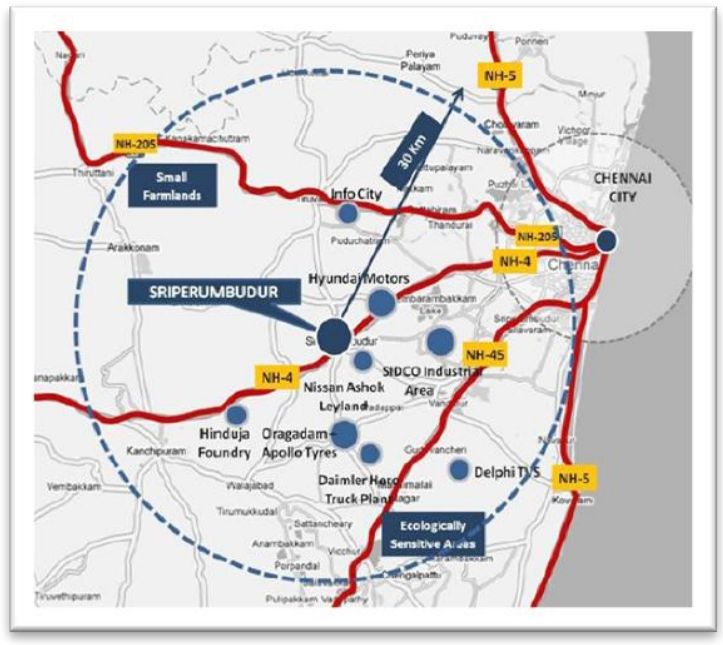

Figure 6: Map showing industrial infrastructure and the national highways around Sriperumbudur 4.3Soil survey

To determine the type of soil. This assists the design of runway, taxiway, terminal buildings and the drainage system. Geologically, Sriperumbudur belongs to the Sriperumbudur Formation which is characterized by erinaceous and argillaceous rock units comprising of splintery green shale, clays and sandstones with ironstone intercalation and conformably overlying either the Precambrian basement or Precambrian boulder beds and green shale. The beds contain marine intercalations. Their lithological suites and fossil fauna are suggestive of deposition under shallow and brackish conditions, probably close to the shoreline. Brown clayey soil is the most predominant.

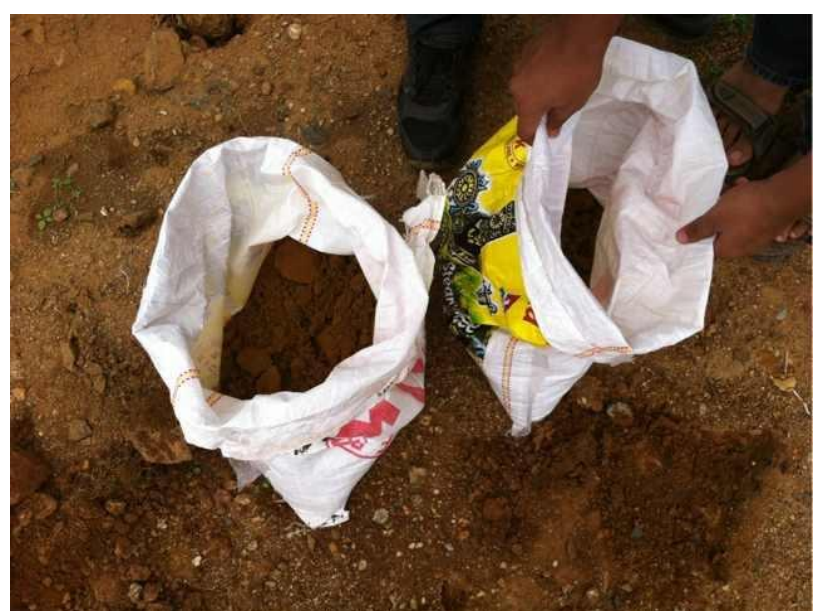

\subsection{Drainage survey}

Figure7: Soil samples from the proposed region at Sriprumbudur.

To determine the quantity of storm water for drainage. This can be done by interpreting rainfall intensity and the contour maps of the area. To determine the possible outlets for draining water in the vicinity of the site.

The present drainage system in the town was well laid with canals and drains. The total length of storm water drains in the town is $6.91 \mathrm{~km}$ against a total road length of $31 \mathrm{~km}$. The average annual rainfall over the district varies from $1105 \mathrm{~mm}$ to $1214 \mathrm{~mm}$ and the maximum rainfall is during north-east monsoon. The town has 14 number of water bodies situated at various locations of the town, which constitute major storm water drainage system in the town. The list of water bodies and the ownership particulars are given below in the table:

Table 2: List of water bodies 
Runway design and structural design of an airfield pavement.

\begin{tabular}{|c|l|c|c|}
\hline SI.No & \multicolumn{1}{|c|}{ Name of the water body } & Ownership & Area (in Ares) \\
\hline 1 & Narasimha Kulam & Temple & 0.35 .0 \\
\hline 2 & Ramapuram kulam & Town Panchayat & - \\
\hline 3 & Ilaneer Kulam & Town Panchayat & 0.89 .5 \\
\hline 4 & Panchalapattu Kulam & Town Panchayat & - \\
\hline 5 & Sivanthangal Kulam & Town Panchayat & 2.24 .5 \\
\hline 6 & Panchalapattu kulam (NH) & Town Panchayat & - \\
\hline 7 & Pattu nool chatram kulam & Town Panchayat & 1.86 .0 \\
\hline 8 & Venkatramapillaichatram kulam & Town Panchayat & 0.73 .0 \\
\hline 9 & Katchipattu Keelandai street kulam & Town Panchayat & - \\
\hline 10 & Thanthontri Amman Koil Street kulam & Town Panchayat & - \\
\hline 11 & Thirumangaiyazhwar kulam & Temple & - \\
\hline 12 & Thirukulam (Ramanujar temple Tank) & Temple & - \\
\hline 13 & Theppakulam & Temple & - \\
\hline 14 & Sriperumbudur Eri & PWD owned & 29.420 m.sq.ft \\
\hline
\end{tabular}

\subsubsection{Drainage pattern}

The general slope of the town is towards north-east leading to Sembarambakkam Lake. The rain water during monsoon is conveyed through the existing network of drains in the town and is let into the above listed water bodies. The excess water from these tanks is drained through the NGO Colony canal which ultimately leads to the Sembarambakkam Lake. Storm water drainage network is intercepted and encroached. Dumping of debris and garbage into the open Nallahs/Drains. Due to this inadequate drainage system is prevailing in this town.

Table 3: Drainage system
\begin{tabular}{|l|l|c|c|c|}
\hline SI.No & Service Indicators & Unit & Benchmark & $\begin{array}{l}\text { Current } \\
\text { Status }\end{array}$ \\
\hline 1 & Length of drains against total road length & percent & 100 & 17 \\
\hline 2 & Incidence of water logging and flooding & Nos & 0 & 11 \\
\hline
\end{tabular} Source: Analysis and Calculations.

\subsection{General}

\section{Runway design}

The runway is a major element of the airport. It is clearly defined area of an airport prepared for landing and/or take off of aircraft. Runways and taxiways should be so planned in relations to other major operating elements such as terminal building, cargo areas, aprons air traffic services and parking etc. to provide an airport configuration offering the maximum overall efficiency. Runways are normally identified by the principal elements.

Runway location and orientation are of the utmost importance to aviation safety, comfort and convenience of operation, environment impacts, and the overall efficiency and economics of the airport. In establishing a new runway layout and/or evaluating existing layouts for improvements where runways are added and/or existing runways are extended, the factor influencing runway location and orientation should be considered. The weight and degree of concern to be given to each factor are in part dependent on the airplane types expected to utilise each runway, the meteorological conditions to be accommodated, the surrounding environment and the volume of air traffic expected to be generated on each runway. Following factors should be considered in location and orienting new runways and/or establishing which end of existing runways should be extended.

1. Location of neighbouring airports.

2. Obstruction and topography.

3. Built up areas and noise.

4. Air traffic control technique.

5. Wind direction and visibility condition.

6. Capacity (type and amount of traffic).

\subsection{Infrastructure requirements of design aircraft}

The following table provides characteristics of A380-800 Models, these data are specific to each Weight Variant:

Table 4: Aircraft Characteristics 
Runway design and structural design of an airfield pavement.

\begin{tabular}{|c|c|c|c|c|c|}
\hline \multicolumn{5}{|c|}{ Aircraft Characteristics } & \\
\hline & WV000 & \begin{tabular}{|l|} 
WV001 \\
\end{tabular} & WV002 & WV003 & MV004 \\
\hline $\begin{array}{l}\text { Maximum Ramp Weight } \\
\text { (MRW) } \\
\text { Maximum Taxi Weight } \\
\text { (MTW) }\end{array}$ & 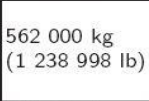 & $\begin{array}{c}512000 \mathrm{~kg} \\
(1128766 \mathrm{lb})\end{array}$ & $\begin{array}{l}571000 \mathrm{~kg} \\
(1258 \quad 839 \mathrm{lb})\end{array}$ & $\left.\mid \begin{array}{cccc}512 & 000 & \mathrm{~kg} \\
(1 & 128 & 766 & \mathrm{lb}\end{array}\right)$ & $\begin{array}{c}562000 \mathrm{~kg} \\
(1238998 \mathrm{lb})\end{array}$ \\
\hline $\begin{array}{l}\text { Maximum Take Off } \\
\text { Weight (MTOW) }\end{array}$ & $\begin{array}{l}560000 \mathrm{~kg} \\
(1234588 \mathrm{lb})\end{array}$ & $\begin{array}{c}510000 \mathrm{~kg} \\
(1 \quad 124357 \mathrm{lb})\end{array}$ & $\begin{array}{l}569000 \mathrm{~kg} \\
(1254 \quad 430 \mathrm{lb})\end{array}$ & $\begin{array}{c}510000 \mathrm{~kg} \\
(1 \quad 124357 \mathrm{lb}) \\
\end{array}$ & $\begin{array}{c}560000 \mathrm{~kg} \\
(1234588 \mathrm{Ib}) \\
\end{array}$ \\
\hline $\begin{array}{l}\text { Maximum Landing } \\
\text { Weight (MLW) }\end{array}$ & $\begin{array}{l}386000 \mathrm{~kg} \\
(850984 \mathrm{lb})\end{array}$ & $\begin{array}{c}394000 \mathrm{~kg} \\
(868621 \mathrm{lb})\end{array}$ & $\begin{array}{l}391000 \mathrm{~kg} \\
(862007 \mathrm{lb})\end{array}$ & $\begin{array}{c}395000 \mathrm{~kg} \\
(870826 \mathrm{lb})\end{array}$ & $\begin{array}{c}391000 \mathrm{~kg} \\
(862007 \mathrm{lb})\end{array}$ \\
\hline $\begin{array}{l}\text { Maximum Zero Fuel } \\
\text { Weight (MZFW) }\end{array}$ & $\begin{array}{l}361000 \mathrm{~kg} \\
(795869 \mathrm{lb})\end{array}$ & $\begin{array}{r}372000 \mathrm{~kg} \\
(820119 \mathrm{lb})\end{array}$ & $\begin{array}{l}366000 \mathrm{~kg} \\
(806892 \mathrm{lb})\end{array}$ & $\begin{array}{l}373000 \mathrm{~kg} \\
(822324 \mathrm{lb})\end{array}$ & $\begin{array}{l}366000 \mathrm{~kg} \\
(806892 \mathrm{lb})\end{array}$ \\
\hline
\end{tabular}

\subsubsection{Aircraft dimensions}

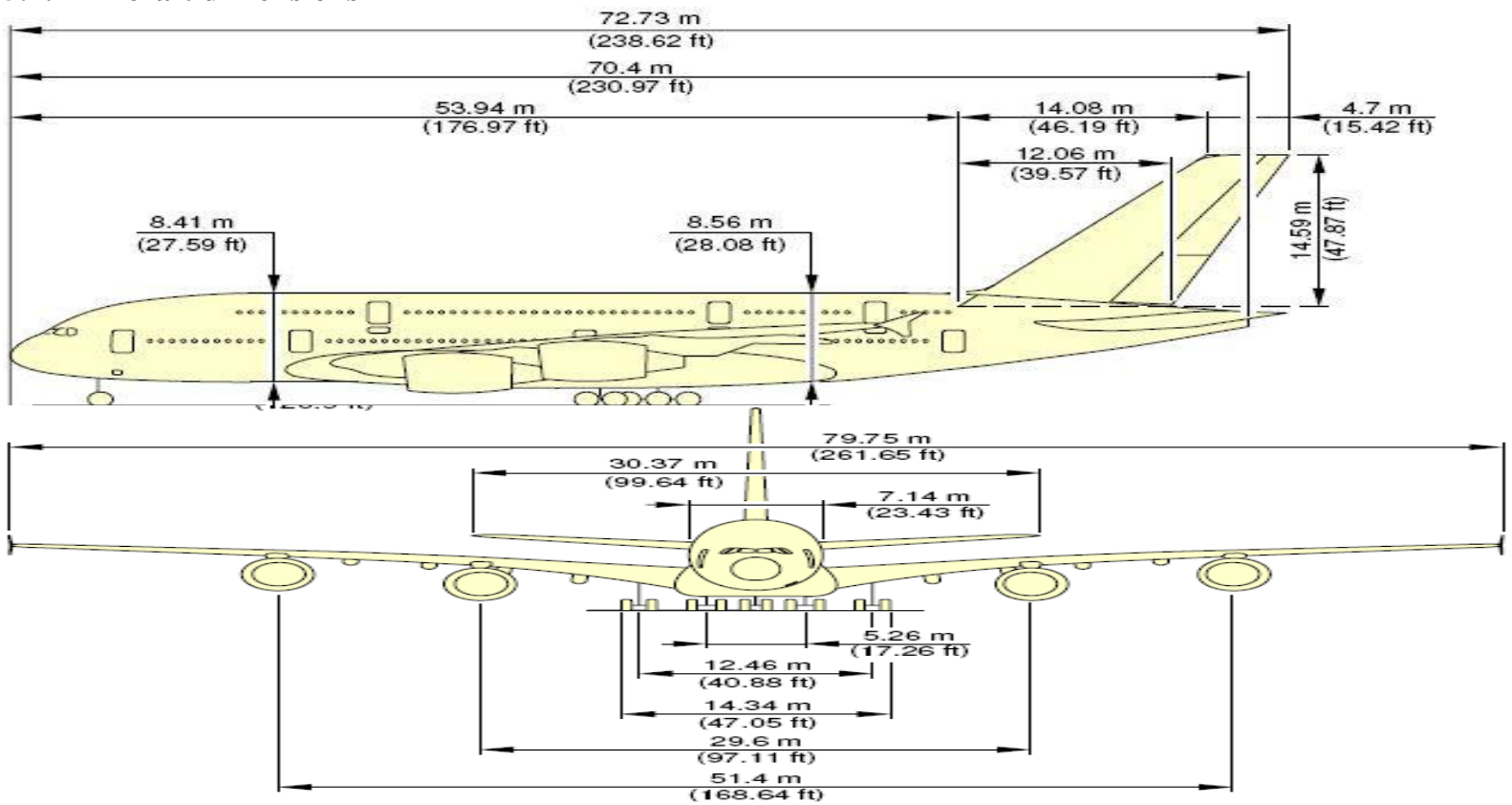

Figure8\&9: Aircraft Dimensions

5.3ICAO code $F$ for new large aircrafts

Summary of ICAO code F Requirements:

Runways

The runway width should be not less than $60 \mathrm{~m}$.

$>$ Runway shoulders are recommended and, if provided, should be at least $7.5 \mathrm{~m}$ in width each side, giving an overall minimum width of $75 \mathrm{~m}$.

$>$ The Obstacle Free Zone (OFZ) shall extend to at least $77.5 \mathrm{~m}$ either side of the runway.

Unless specified, ICAO Code F requirements as detailed above shall be provided.

5.4 A 380 flexible pavement data

- A High Strength: CBR 15

- B Medium Strength: CBR 10

- C Low Strength CBR: 6

- D Ultra Low Strength: CBR 3

- A,B,C\& D are the Subgrade categories.

Table 5: A 380-800 requirements

\begin{tabular}{|l|l|}
\hline Runway width & $60 \mathrm{~m}$ \\
\hline Runway shoulder & $7.5 \mathrm{~m}$ \\
\hline Obstacle free zone & $77.5 \mathrm{~m}$ either side of centre line \\
\hline Rumway holding positions & $107.5 \mathrm{~m}$ from centre line \\
\hline Taxiway width & $25 \mathrm{~m}$ \\
\hline Taxiway shoulder & $17.5 \mathrm{~m}$ \\
\hline $\begin{array}{l}\text { Taxiway centre line to Code 4 } \\
\text { Tastrument runway }\end{array}$ & $190 \mathrm{~m}$ \\
\hline $\begin{array}{l}\text { Taxiway centre line to Code } 4 \\
\text { non-instrument rumway }\end{array}$ & $115 \mathrm{~m}$ \\
\hline
\end{tabular}

Minimum Take-off distance \& landing roll is $9020 \mathrm{ft}(2750 \mathrm{~m})$ 


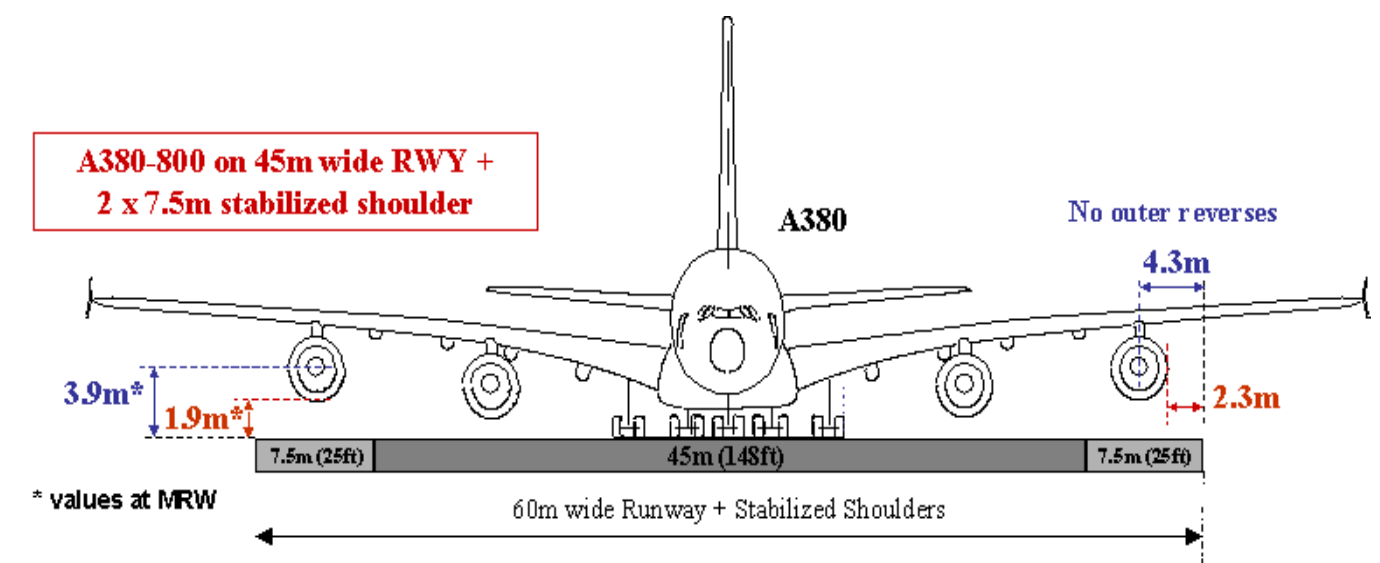

Figure 10: A380-800 requirements

\author{
5.5 Determination of actual runway length \\ Runway Specifications for design: \\ $>$ Basic Runway Length: $3000 \mathrm{~m}$ \\ $>$ Runway Width: 60m \\ $>$ Stabilised shoulder: $7.5 \mathrm{~m}$ \\ $>$ Obstacle free zone: $77.5 \mathrm{~m}$ either side of the centre line \\ $>$ Effective Runway Gradient: $0.30 \%$
}

Determination of actual length of runway to be provided:

$>$ Correction for Elevation:

The basic length has to be increased at the rate of $7 \%$ per $300 \mathrm{~m}$ elevation above mean sea level.

The proposed airport site is at an elevation of just $37 \mathrm{~m}$ from mean seal level so the correction for elevation is not required.

$>$ Correction for Temperature:

Airport reference temperature $=[\mathrm{T} 1+\{(\mathrm{T} 2-\mathrm{T} 1 / 3)\}]=31.27 \mathrm{C}$

$\mathrm{T} 1=$ Mean of average daily temperature recorded during the year 2012-13 at Sriperumbudur $=25.3 \mathrm{C}$

$\mathrm{T} 2=$ Maximum of average daily temperature recorded during the year 2012-13 at Sriperumbudur $=$ $43.2 \mathrm{C}$

Standard atmospheric temperature at MSL $=15 \mathrm{C}$

Rise in temperature $=31.27-15=16.27 \mathrm{C}$

Applying correction at the rate of $1 \%$ for every $1 \mathrm{C}$,

Correction for temperature $=(0.001 * 3000) * 16.27=48.81 \mathrm{~m}$

Corrected length $=3048.81$

There is no combined correction as the correction for elevation is not there.

$>$ Correction for Gradient:

Effective Runway gradient $=($ Difference in elevation along the proposed profile of runway $/$ Basic Runway Length) $* 100=0.30 \%$

Applying correction for the effective gradient at the rate of $20 \%$ for each $1 \%$ effective gradient.

Correction for gradient $=(0.2 * 3048.81 * 0.30)=182.93 \mathrm{~m}$

$>$ Actual length of Runway $=3048.81+182.93=\mathbf{3 , 2 3 0 m}$ (approx.)

\title{
6.1 General
}

\section{Orientation of the runway}

Wind is a key factor influencing runway orientation and the number of runways. Ideally, a runway should be aligned with the prevailing wind. Wind conditions affect all aircraft in varying degrees. Generally, the smaller the aircraft, the more it is affected by wind, particularly crosswind components which are often a contributing factor in small aircraft accidents.

\subsection{Analysing wind data}

The most common wind analysis procedure uses a windrose which is a scaled graphical presentation of the wind information. Each segment of the windrose represents a wind direction and speed grouping corresponding to the wind direction. The purpose of the analysis is to determine the runway orientation which provides the greatest wind coverage within the allowable crosswind component limits. 


\subsection{Computerised wind analysis}

In designing runway orientation, the most desirable runway is one that has the largest wind coverage and minimum crosswind components.

The WindRose PRO software can be used for analysing a long series of data and calculating, for each possible runway direction, the wind coverage and the crosswind components (maximum, average and median). The software can also be used to evaluate the correct orientation of an existing runway. Moreover, since WindRose PRO allows date/time filtering of the input data, it is possible to evaluate the wind coverage and the crosswind components even for airports which work only in particular seasons (for example during summer) or only during day time.The following steps illustrates the procedure followed using the software tool:

Step 1: Conversion meteorological reports in to a spreadsheet file.xls: Data collected needs to be changed in to the specified units that the database file can take. This needs to be done manually or by using an Optical Character Recognition software (OCR). Manual Conversion needs to be done with utmost care when it deals with the direction of wind flow. Wind speed in $\mathrm{Km} / \mathrm{h}$ should be converted in to $\mathrm{m} / \mathrm{s}$. Utilising a computer program would make this process easier. The whole plot is assumed to be formed of segments of each 22.5 degree.

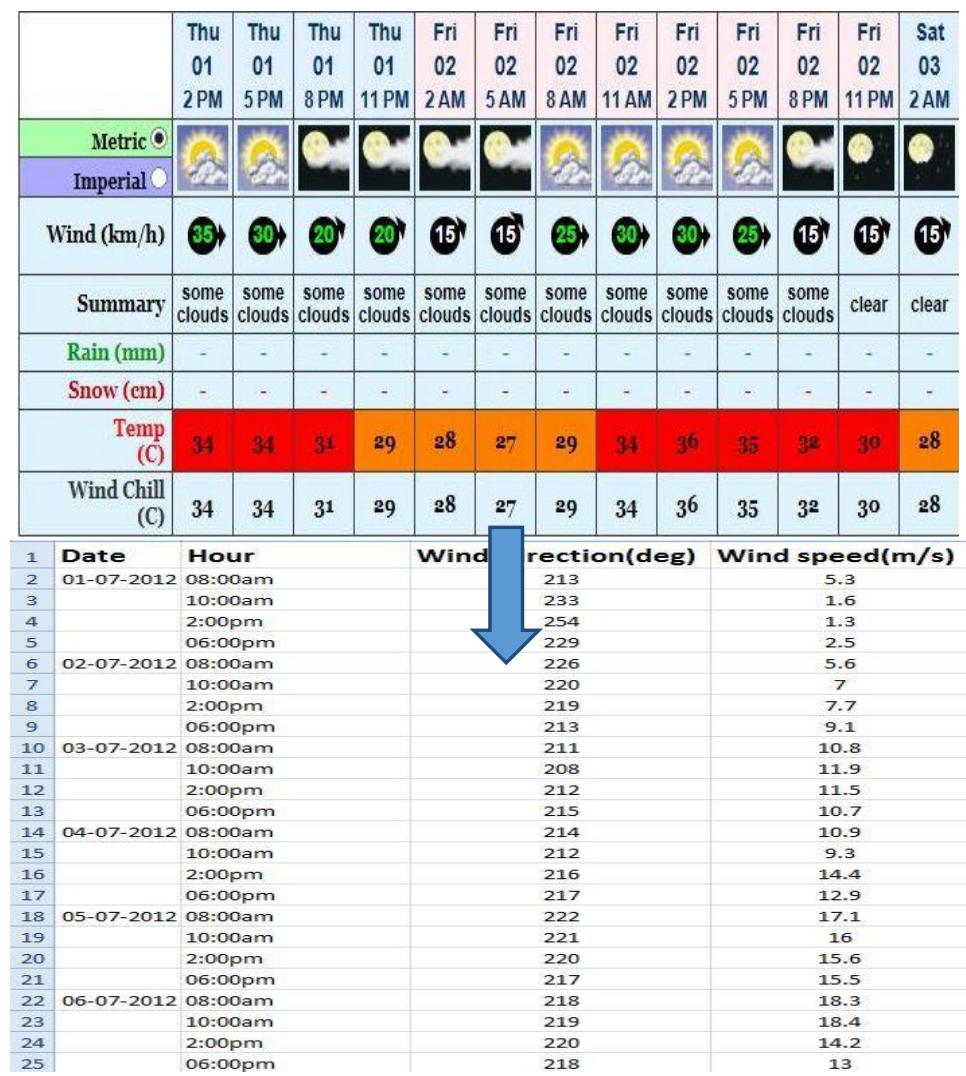

Figure 11: MeteorologicalReport to Database Spreadsheet conversion.

Step 2: Loading of data, substitutions and assigning columns with directions and data. 


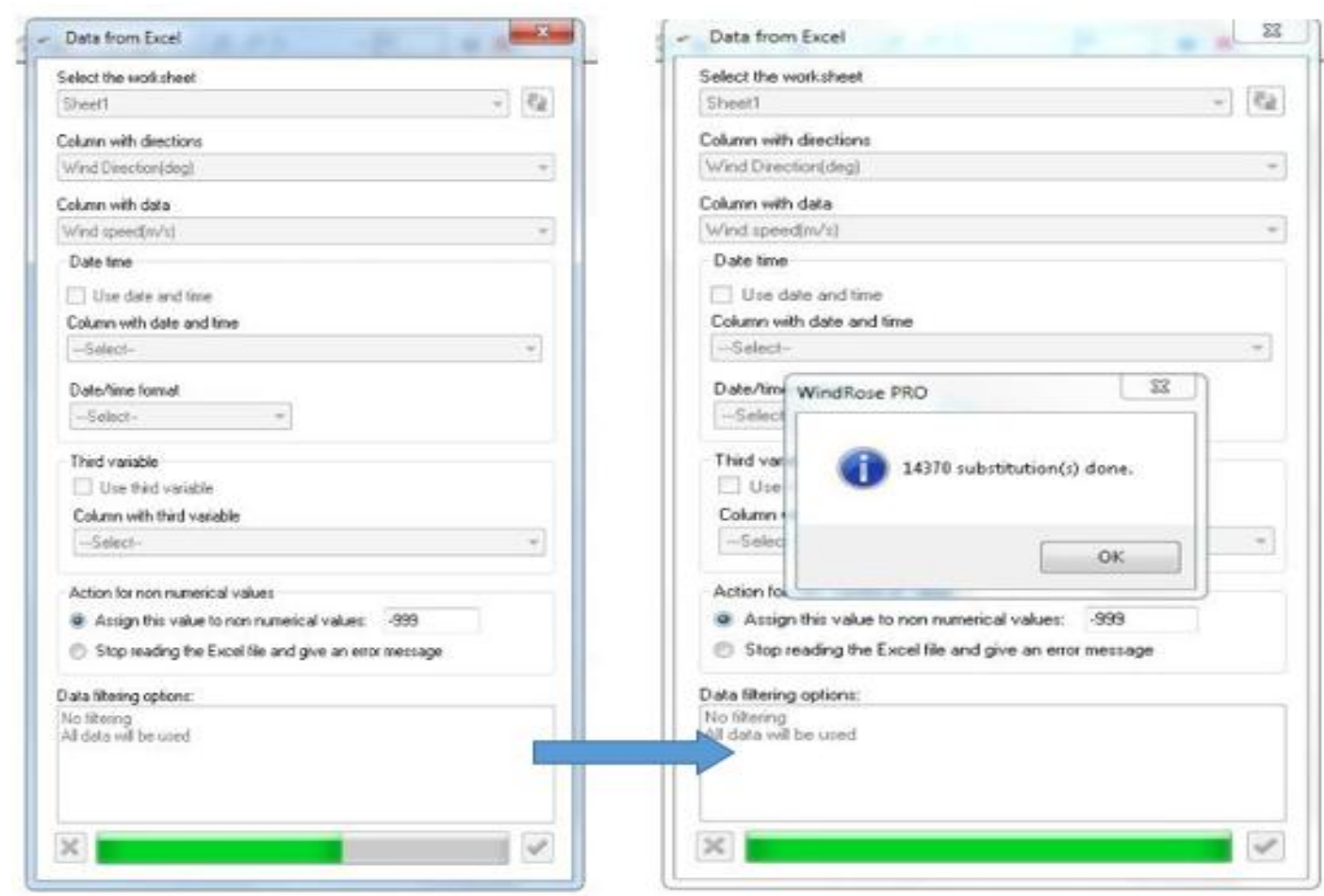

Figure 12: Loading \& Substitution

Step 3: Compute \& Analyse the raw wind data to plot the windrose.

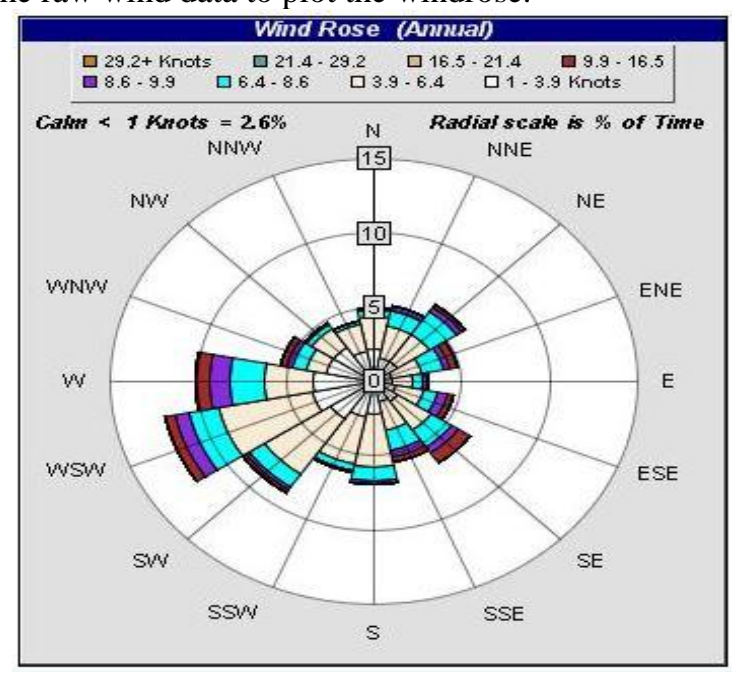

Figure 13:Windrose diagram of the proposed airport site at Sriperumbudur. 

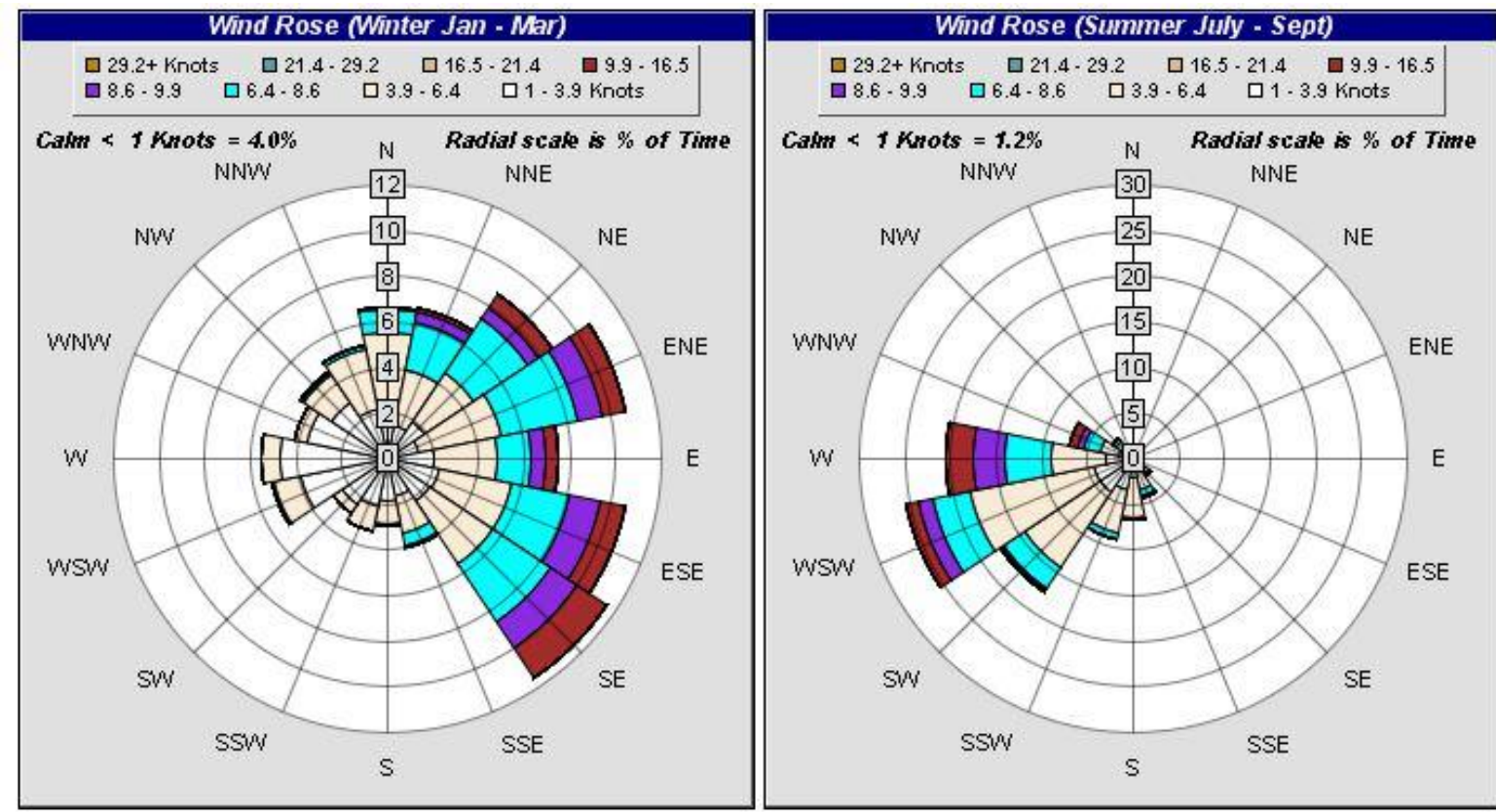

Figure 14: Windrose plot during winter $\&$ summer season.

Step 4: Calculation of crosswind component

Runway design mode in the software is enabled and the crosswind component calculation option is clicked.

Mark the crosswind calculation and enter the design crosswind component for the runway.

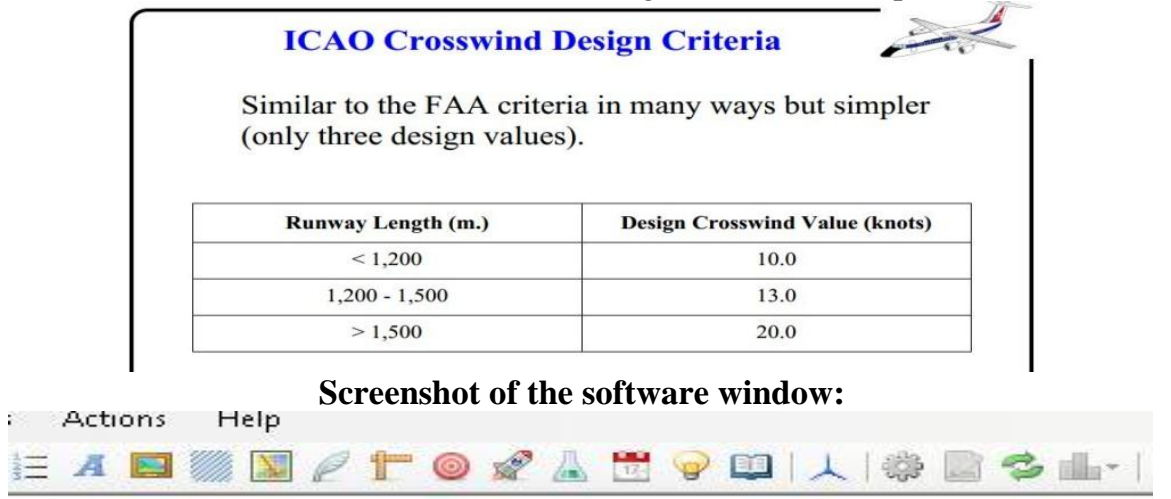

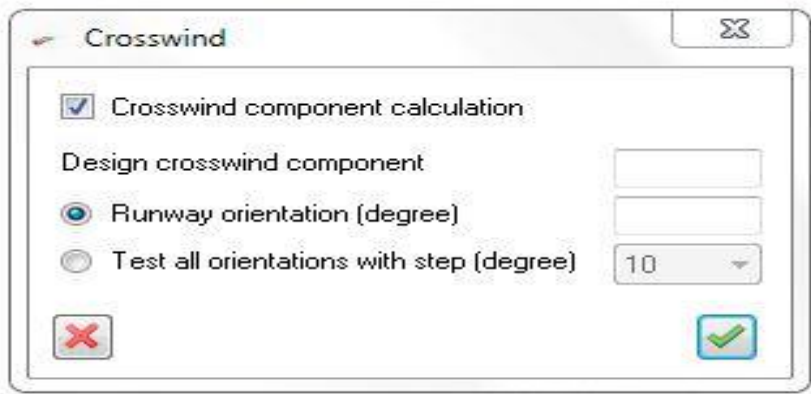

The value or the degree of Runway Orientation can be obtained from the wind analysis report. The design crosswind component chosen is $20 \mathrm{knots}$ and this should be converted in to $\mathrm{m} / \mathrm{s}$ and given as input. 
$1 \mathrm{knot}=0.51444 \mathrm{~m} / \mathrm{s}$

Based on the output generated and the analysis of the windrose diagram the following is proposed:

The most advantageous runway orientation based on wind is the one which provides the greatest wind coverage with the minimum crosswind components. Construction of two runways may be necessary to achieve the desired 95.0 percent wind coverage.

\subsection{Proposed orientation}

Non-intersecting Runways which are divergent towards SOUTH-EAST and WEST of SOUTH-WEST are proposed to ensure the $95.0 \%$ wind coverage and operation during most of the time in all the seasons.

Divergent flight paths have the capacity of the order of operations from 80 to 110 per hour under Visual Flight Rules (VFR) / (Clear weather) where cloud ceiling will be less than $300 \mathrm{~m}$.

Runway capacity is normally less under Instrument Flight Rules (IFR) conditions where visibility is less than 4.8 Km (3 miles).

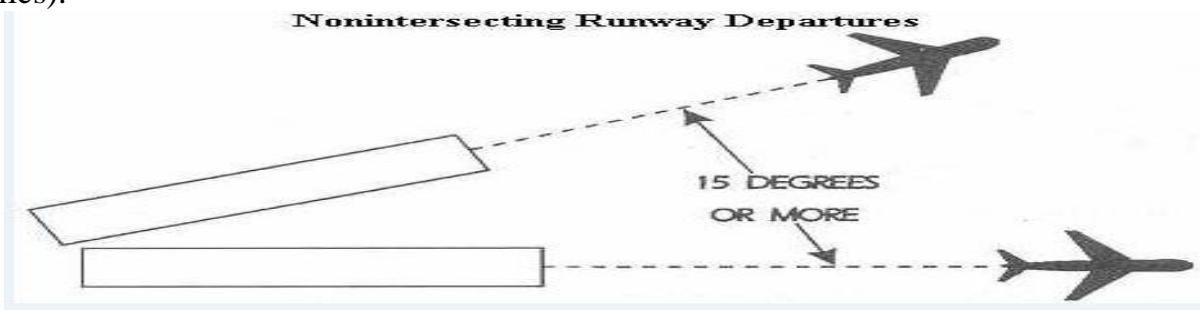

Figure 15: Non Intersecting Runway Departures

\subsection{Definition}

\section{Structural design of flexible airfield pavement}

The term structural design of pavements refers to the determination of the thickness of the pavement and its components.

\subsection{Flexible airfield pavement}

Flexible pavements are so named because the total pavement structure deflects, or flexes, under loading. A flexible pavement structure is typically composed of several layers of materials. Each layer receives loads from the above layer, spreads them out, and passes on these loads to the next layer below. Thus the stresses will be reduced, which are maximum at the top layer and minimum on the top of subgrade. In order to take maximum advantage of this property, layers are usually arranged in the order of descending load bearing capacity with the highest load bearing capacity material (and most expensive) on the top and the lowest load bearing capacity material (and least expensive) on the bottom. For flexible pavements, structural design is mainly concerned with determining appropriate layer thickness and composition. The main design factors are stresses due to traffic load and temperature variations.

\subsection{Airfield pavement design software tools}

The following list of software tools can be used to do the structural design of airfield pavements:

1) F806FAA.xls spreadsheet

2) FAARFIELD 2.5

3) LEDFAA13

These softwares were designed to produce flexible pavement design thickness in accordance with FAA Advisory Circular (AC) AC 150/5320-6D.

\subsection{Computrised structural design of airfield pavement}

It is well known that the current pavement-design procedures do not accurately predict the load interaction of closely spaced landing gears on these new-generation aircraft. Thus it is not always evident that the conventional FAA procedure, which is based on the U.S. Army Corps of Engineers (USACE) procedure for calculating pavement thicknesses, is correct for these new types. This uncertainty is supported by the fact that thickness-design curves have not yet been included in the preliminary technical publication for the Airbus A380. In this context, the design software tools developed by the FAA are the only alternatives that could give compatible results.F806FAA.xls spreadsheet is used to do this structural design of a flexible pavement.

The following steps are to be followed in order to ensure appropriate results:

Step1:General Information 


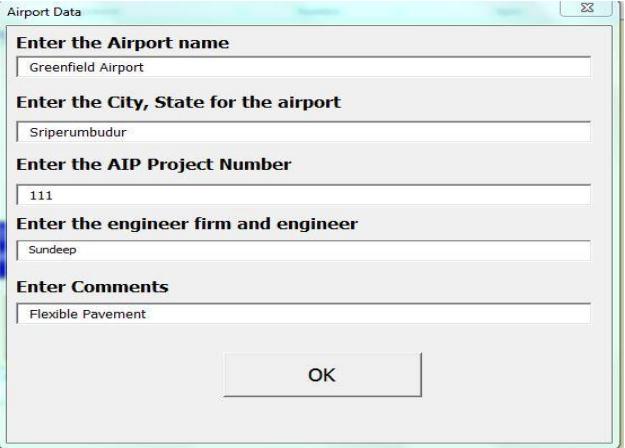

Provides general project data which is displayed with the design summary.This information is optional and does not affect numerical calculations.

\section{Step 2:Subgrade CBR}

Enter the subgrade CBR value as defined in the A $\mathbf{3 8 0}$ manual supplemented by the manufacturer.

A 380 Flexible Pavement Data:

A High Strength: CBR 15

B Medium Strength: CBR 10

C Low Strength CBR: 6

D Ultra Low Strength: CBR 3

A,B,C\& D are the Subgrade categories.

Remember that the CBR design method requires that each layer be an improvement over the layer directly beneath, i.e. the sub-base layer CBR must be higher than the subgrade CBR.

- Assuming the subgrade to be of high strength and so the corresponding $C B R=15$.

\begin{tabular}{|l|l|}
\hline Subgrade CBR Value & \multicolumn{1}{|c|}{ Enter the Subgrade CBR Value } \\
& \\
& \\
\hline 15 & OK \\
\hline
\end{tabular}

Note: High values of CBR (i.e. >20) may not be appropriate for this design method. Thickness results from high CBR subgrade layers may appear incorrect as the program will default to minimum thickness requirements as identified in 150/5320-6D. Designs performed with high subgrade CBR values may indicate negative sub-base layer thickness.

\section{Step 3: Subgrade Soil Frost Condition}

If frost consideration is appropriate, the spreadsheet calculates the pavement thickness necessary for a Reduced Subgrade Strength in accordance with paragraph 308 of AC 150/5320-6D.

Sriperumbudur geology has Non Frost Conditions and so choose the appropriate option.

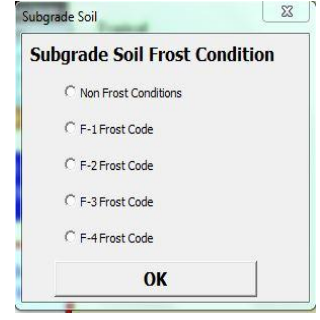

Step 4:Number of Sub-bases

Determine the number of sub-base layers to be included in the design. The spreadsheet can design for a maximum of 3 sub-base layers, however, most design requirements do not need the additional layers to provide sufficient pavement strength.

A design with multiple sub-base layers tends to over-design the lower layers and under-design the upper layers. This is because the methodology is to determine the total thickness required over the subgrade material then subtract the thickness required over the first improved layer. The thickness of subsequent layers is subtracted from the remaining thickness. 
For example if a total thickness of 35 inches is required over the subgrade and a thickness of 15 inches is required over a sub-base of $C B R=20$, then the sub-base layer would be 35-15=20 inches thick. This only leaves 15 inches to be distributed to any remaining layers.

$>$ Due to construction practicalities and cost feasibility, most typical designs only incorporate one subbase layer.

Enter the CBR value for the sub-base material

The user is reminded that AC 150/5320-6D assumes a CBR of 20.

$>$ Sub-base CBR $=20$.

The inputs given for the subbase calculations are given below in their order or sequence:

1. Determination of no of subbases

2. Subbase CBR value

3. Subbase frost condition

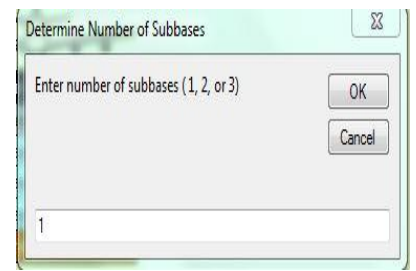

*Only one layer of sub-base is chosen above the subgrade.

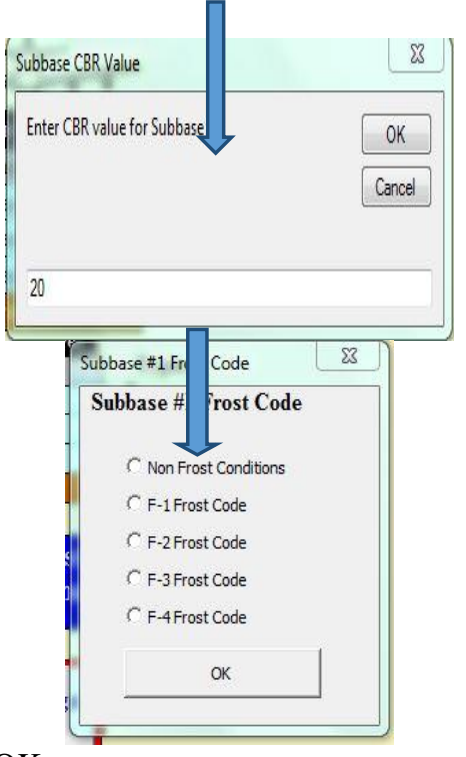

*Choose Non Frst Conditions and press OK

\section{Step 5. Default Aggregate Base Material}

$>$ Item P209 is the default material for granular base.

$>$ It is assumed that P-209 material can achieve a minimum CBR value greater than 80 .

$>$ Others base materials, when permitted, will increase the asphalt surface course minimum thickness.

$>$ If Item P-209 is not the default base material, the minimum thickness of the surface asphalt layer is automatically increased to 5 inches.

$>$ Item P-208 is permitted when aircraft are not expected to exceed a gross weight of 60,000 pounds.

Choosing Item P209 as the default aggregate base material.

Item P209 refers to the Crushed Aggregate Base Course.

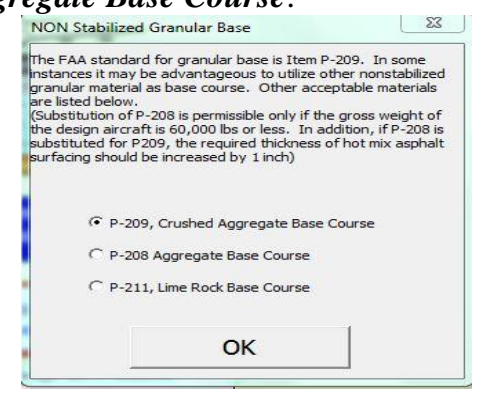




\section{Step 6. Frost Penetration}

Enter the degree days ${ }^{\circ} \mathrm{F} /$ day and subgrade unit weight $\mathrm{lb} / \mathrm{ft}$.

This is an optional step and does not affect pavement thickness calculations. The user should compare the frost depth to the required protection depth. Computation of the frost depth is not necessary when the pavement design is based upon the Reduced Subgrade support method of frost design.

The values can be obtained from Table 20.1 Frost Penetration

\section{Frost Penetration (Inches)}

\begin{tabular}{|c|c|c|c|c|}
\hline & \multicolumn{4}{|c|}{ Soil Unit Weight Ib/cf } \\
\hline Degree Days & $\mathbf{1 0 0}$ & $\mathbf{1 1 5}$ & $\mathbf{1 2 5}$ & $\mathbf{1 5 0}$ \\
\hline $\mathbf{2 0 0}$ & 20.5 & 21.5 & 23.8 & 25.5 \\
\hline $\mathbf{4 0 0}$ & 27.5 & 30.5 & 35 & 38.5 \\
\hline $\mathbf{6 0 0}$ & 34 & 38 & 44.5 & 49 \\
\hline $\mathbf{8 0 0}$ & 40 & 44.5 & 54 & 59 \\
\hline $\mathbf{1 0 0 0}$ & 45 & 51 & 62 & 69 \\
\hline $\mathbf{2 0 0 0}$ & 69.5 & 79 & 102 & 113 \\
\hline $\mathbf{3 0 0 0}$ & 92 & 105 & 140 & 156 \\
\hline $\mathbf{4 0 0 0}$ & 115 & 130 & 177 & 205 \\
\hline $\mathbf{4 5 0 0}$ & 125 & 145 & 197 & 225 \\
\hline
\end{tabular}

This step is neglected.

\section{Step 7: Enter Aircraft Data}

The user can assign a local name to an aircraft for ease of identification. Local names can be entered directly into the spreadsheet. This is particularly useful when numerous aircraft are from a common gear configuration but vary in weight.

The program will prompt the user for aircraft weight and annual operations. Since each gear type is based upon a reasonable anticipated weight for the gear configuration, the program will limit the permissible weight range. If desired, the user may over-write these values directly in the spreadsheet. The user is cautioned to observe the weight limitations and select gear configurations appropriately. Greater thickness requirements will result from overloading a small gear versus under loading a larger gear. For example, a dual wheel aircraft weighing 125,000 pounds could be input as a DUAL100 or a DUAL150 aircraft.

Step 8: Find Required Thickness for each aircraft

\begin{tabular}{|c|c|c|c|c|c|}
\hline 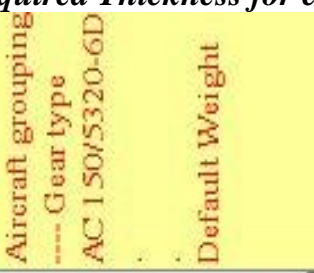 & & 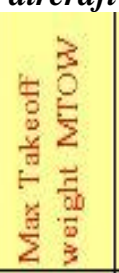 & 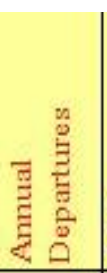 & 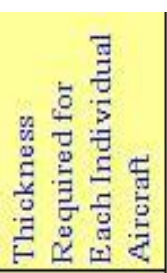 & \\
\hline BOEING747 $-780,000 \mathrm{lbs}$ & $\nabla$ & $7,80,000$ & 180 & 18.32 & \\
\hline DC- $10-30-590,000 \mathrm{lbs}$ & $\checkmark$ & $5,90,000$ & 80 & 17.08 & \\
\hline$B-1-480,000$ & $\nabla$ & $4,80,000$ & 60 & 17.30 & \\
\hline $\mathrm{L}-1011-500,000 \mathrm{lbs}$ & $\nabla$ & $5,00,000$ & 30 & 15.72 & \\
\hline $\mathrm{A} 300 \mathrm{~B} 4-400,000 \mathrm{lbs}$ & $\nabla$ & $4,00,000$ & 180 & 17.68 & \\
\hline BOEING757- $-400,000 \mathrm{lbs}$ & $\nabla$ & $4,00,000$ & 210 & 18.90 & Recommended Critical Aircraft \\
\hline BOEING767 $-400,000 \mathrm{lbs}$ & $\nabla$ & $4,00,000$ & 120 & 16.50 & \\
\hline $\mathrm{A} 300 \mathrm{~B} 2-400,000 \mathrm{lbs}$ & $\nabla$ & $4,00,000$ & 80 & 16.74 & \\
\hline DC- $10-10-450,000 \mathrm{lbs}$ & $\nabla$ & $4,50,000$ & 60 & 15.90 & \\
\hline DUALTAN400 $-400,000 \mathrm{lbs}$ & $\nabla$ & $4,00,000$ & 80 & 16.99 & \\
\hline
\end{tabular}

Input the kind of Aircraft based on its gear type and also its number of annual departures.

Click find thickness button and it finds and displays the required pavement thickness for each aircraft in the mixture and determines the most demanding (critical) aircraft. 


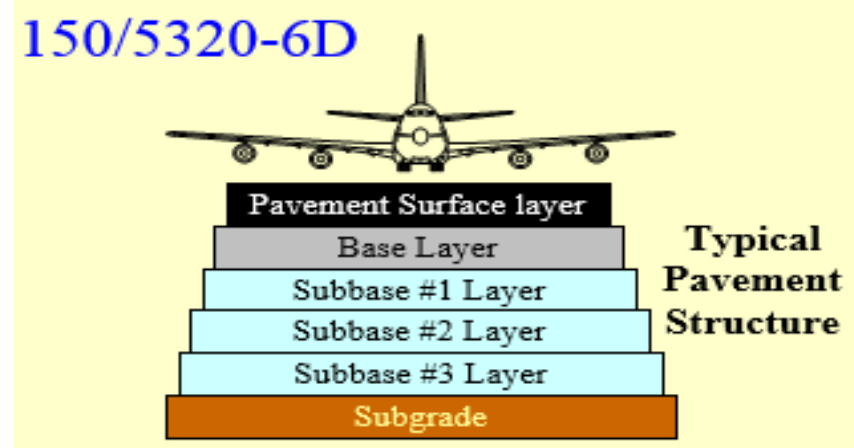

Figure16: Typical Flexible pavement Structure in F806FAA.xls

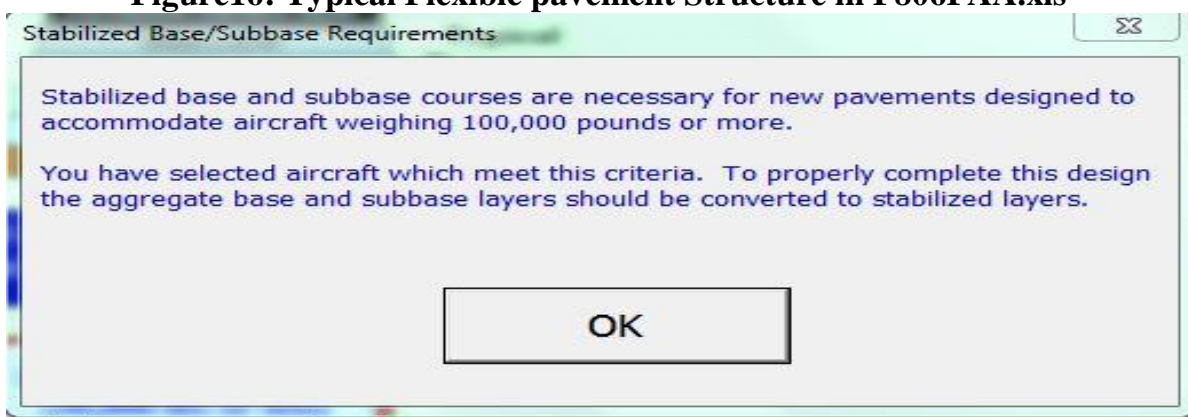

Step 9: Compute for Stabilised layers

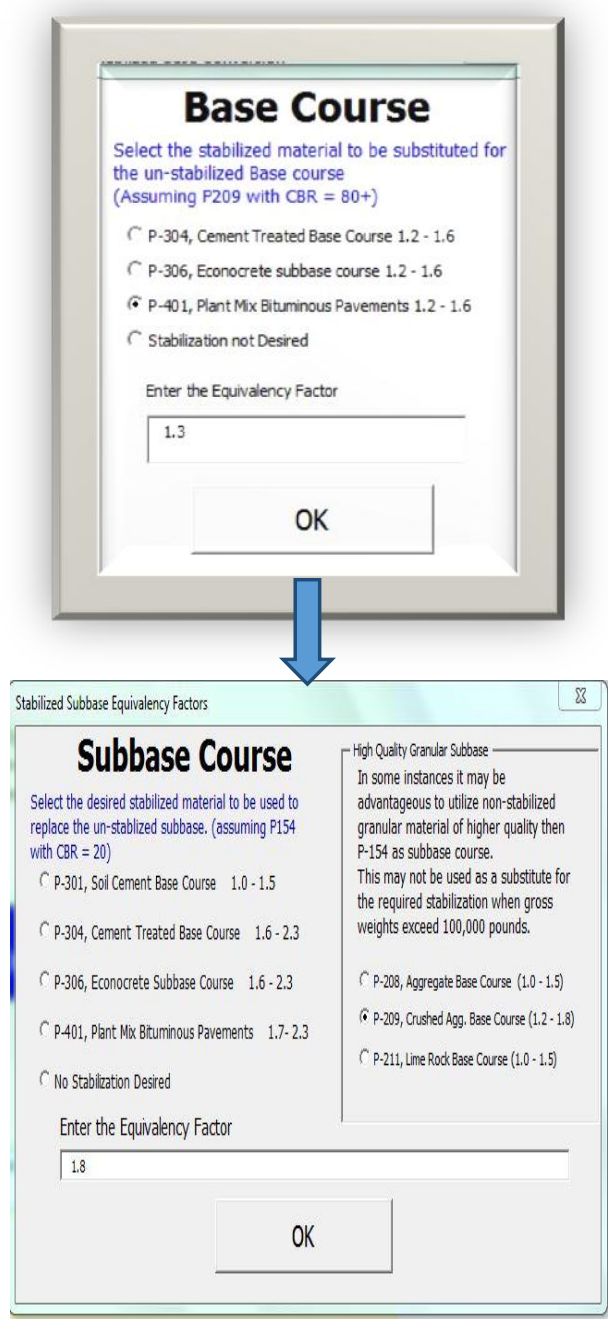




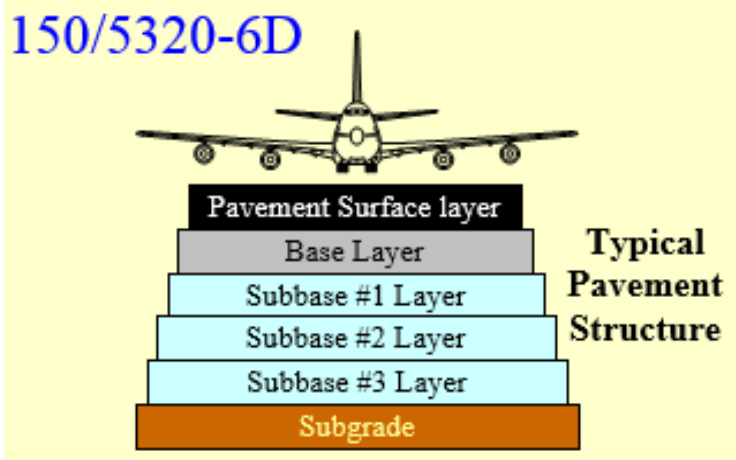

High strength subgrade with CBR 15

Sub-base \#2 and \#3 are eliminated.

Step 10: Click "Go design summary"

The structural design of the runway gives the following results and the detailed report.

Total Thickness of Flexible Airfield Pavement = 20.5" (inches)

Details of a Stabilised Cross Section of the designed flexible pavement:

$>$ Surface layer: 5" Plant Mix Bituminous Pavement

$>$ Base layer: 9" Plant Mix Bituminous Pavement

$>$ Sub-base layer: 6.5" Crushed Aggregate

Base layer and the Sub-base layers should be stabilised to accommodate aircrafts weighing more than 100,000 lbs.

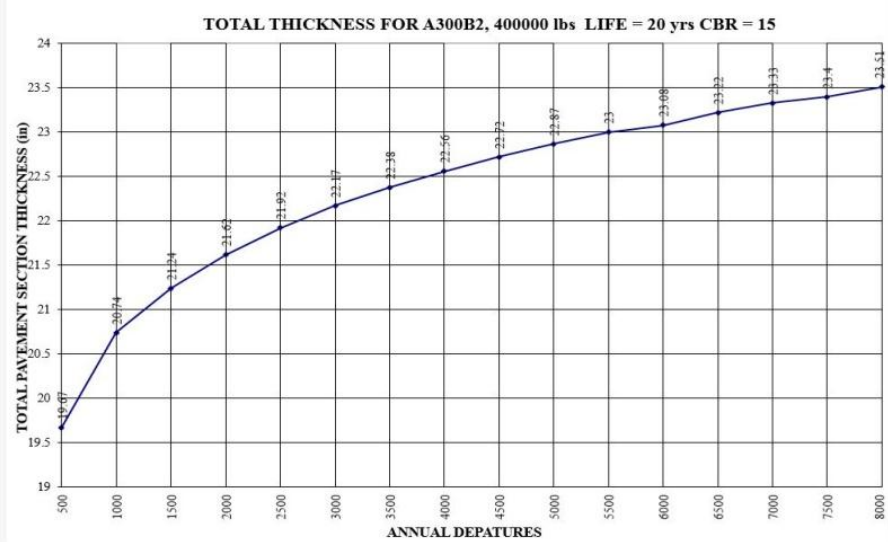

Figure 17: Total Thickness Vs. Annual Departures

\section{Conclusion}

At present, the Airport Authority of India in collaboration with the Government of Tamil Nadu is in the process of acquiring land for the proposed Greenfield Airport at Sriperumbudur near Chennai. The information regarding the above mentioned airport ise presented in a systematic manner as a feasibility report and also it covers what is needed for a detailed project report in which the airport planning, site selection and related surveys, airport design standards, environmental guidelines are incorporated as one part. The other part concentrates on the design aspects of runway and its structural design which includes the region specific and real time collection of field data, computerized wind analysis and Orientation of the runway. Computerized system of design is discussed and solutions are arrived in detail. The runway is designed for the current trend new large aircrafts by considering their future increase in the number of annual departures. This is one of the comprehensive effort to focus the preliminary report preparation of a typical airport's runway design.

Runway geometry and orientation along with the structural design of the flexible airfield pavement are obtained successfully by using software tools which are strictly in accordance with the ICAO design criteria and FAA guidelines (Advisory Circular). 


\section{References}

[1] City development plan, Sriperumbudur, Tamil nadu urban infrastructure financial services limited, Directorate of town panchayats, Government of Tamil nadu.

[2] Airport runway location and orientation, Dr.Antanio A. Trani, Virginia Tech.

[3] Runway length requirements analysis, Dayton international airport master plan update, Landrum \& Brown, Inc. Draft, February 9 , 2005 .

[5] Advanced design of flexible aircraftPavements, Leigh Wardle, Mincad Systems, Australia, Bruce Rodway, Pavement Consultant, Australia.

[6] Airport Layout and Design, Trent Baldwin \& Jim Clague of PBS\&J.

[7] Thickness design calculations for the new large aircraft (NLA) airbus a380, Moshe Livneh, Transportation Research Institute, Technion-Israel Institute of Technology, Haifa 3200,Israel.

[8] WindRose PRO 3 User's guide - version 2013-06-06, Environwaresrl.

[9] Re-Write of 'Airport Design', A New Focus for Advisory Circular 150/5300-13, Kenneth Jacobs, FAA Airport Engineering division.

[10] Federal Aviation Administration, Advisory Circular, AC150/5300-13A.

[11] Aircraft characteristics, Airport and maintenance planning. Airbus, A380.

[12] Interim aerodrome requirements for the A380, Aeronautical Services Unit, Civil Aviation Authority of New Zealand.

[13] Multiple-gear analysis for flexible pavement design in LEDFAA,David r. Brill and Gordon F.Hayhoe, FAA airport technology R\&D branch, William j. Hughes technical centre, Atlantic city international airport, NJ, USA.

[14] Unified Facilities Criteria (UFC), Pavement design for airfields.

[15] Sustainable Airport Planning,Design and Construction Guidelines for Implementation on All Airport Projects, Version 5.0 • February 2010, LA World Airports.

[16] Design guide for airport pavements, National Crushed Stone Association. 